\title{
Phytochemical, cytotoxicity and antioxidant activities of the stem bark of Piper arborescens
}

\author{
Nicholas Daniel a,b, ${ }^{,}$, Fasihuddin Badruddin Ahmad a, Zaini Assim a, Chua Hun Pin b \\ a Department of Chemistry, Faculty of ResourceScience and Technology, University Malaysia Sarawak, 94300 Kota Samarahan, Sarawak, Malaysia \\ ${ }^{b}$ Food Science \& Technology Research Centre, Malaysian Agricultural Research and Development Institute, MARDI Kuching, Lot 411 Block 14, \\ Sultan Tengah Road, Petra Jaya, 93055 Kuching, Sarawak, Malaysia
}

* Corresponding author: nicholas@mardi.gov.my

\section{Article history}

Received 8 June 2017

Accepted 2 October 2017

\begin{abstract}
Crude extract from stem bark of $P$. arborescens was fractionated by using column chromatography to isolate and purify its metabolite content. Six secondary metabolites were successfully isolated and their identification was performed by using Gas Chromatography - Mass Spectrometry (GC-MS), Nuclear Magnetic Resonance (NMR) and Fourier Transform Infrared (FTIR) spectoscopy. The isolated metabolites were identified as caryophyllene oxide (1), $\alpha$-bisabolol (2), benzamide 2-(methylamino) (3), 2-ethylpiperidine (4), piperine (5) and methyl eugenol (6). Toxicity test on the four crude extracts of $P$. arborescens shows high cytotoxicity against Artemia salina brine shrimp with $\mathrm{LC}_{50}$ values ranging from 13.12 to $58.70 \mu \mathrm{g} / \mathrm{mL}$. Greater cytotoxicity of the crude extracts of $P$. arborescens indicated the presence of potent cytotoxic components in this Piperspp. Antioxidant assay of $P$. arborescens against 2-diphenyl-1-picrylhydrazyl (DPPH) indicated moderate antioxidant activities of methanol, dichloromethane, chloroform and hexane crude extracts with $\mathrm{EC}_{50}$ values of $21.68,23.82,32.88$ and $36.88 \mu \mathrm{g} / \mathrm{mL}$, respectively. It is suggested that the six secondary metabolites identified in $P$. arborescens contribute as an active content for the cytotoxicity and antioxidant activities. This study showed that the crude extracts of $P$. arborescens is definitely having potential to be used as a source of natural product of various application.
\end{abstract}

Keywords: Piper arborescens, phytochemical, cytotoxicity, antioxidant

\section{INTRODUCTION}

Most of indigenous Piper plants in Borneo are future potential herbs but still underutilized and scientific information on its phytochemical and biological activities are very scarce. Piper spp. which is widely distributed over the tropical and subtropical regions of the world is used medicinally in various manners. Beside the well studied of the commercial black pepper (Piper nigrum) and the abundance of Piper aduncum (Liew et al., 2000; Micheal \& Douglas, 2014), studies on other wild Piper spp. in the state of Sarawak and Sabah of Borneo region, particularly on the phytochemical and biological activity is a potential and interesting field to be explored. This indigenous Piper spp. can be introduced as a potential herb and cultivated as future crops, where further research can be conducted to provide sufficient information on the health beneficial properties of the plants and their specific usage.

This paper discusses phytochemical and biological activities of a wild Piper spp. that can be found in the forest mostly throughout Sarawak; namely $P$. arborescens or locally known as lada hutan. Few studies on this Piper spp. have been conducted previously mostly focusing on its leaves and stems, but there are still potential elements to discover. A study by Lee et al. (2004) in Taiwan have discovered cyclobutanoid amides from the stem and leaves of $P$. arborescens, while a study by Tsai et al. (2005) also in Taiwan have discovered cytotoxic cyclobutanoid amides and furanoid lignan from the stem of $P$. arborescens. Toxicity of the plants does not always indicated its danger or outright toxicity toward human, but may also suggest the presence of cytotoxic component that may contribute to antitumor or anticancer activities (Moshi et al., 2010). There are various useful method available for assessment of cytotoxicity of the plant extract. The most common and widely used is the Brine Shrimp Lethality assay by using Artemia salina (Mentor et al., 2014). Artemia salina is an invertebrate inhibiting saline aquatic which suitable to be used in laboratory assay for cytotoxicity screening of the plants by estimation of lethality concentration to kill $50 \%$ ( $\left.\mathrm{LC}_{50}\right)$ of the test organism.

In this study, the focus is on the stem bark of $P$. arborescens, which the parts are believed associated to medicinal purposes, yet the related scientific literature are very limited. The stem bark of the $P$. arborescens was extracted using several solvents to obtain the crude extracts, followed by various series of chromatographic method such as column chromatography and thin layer chromatography for separation and purification of the secondary metabolites. The isolated metabolite was further analyzed using Gas Chromatography - Mass Spectrometry (GC-MS), Nuclear Magnetic Resonance (NMR) and Fourier Transformed Infrared (FTIR) for identification and confirmation of the compound. The crude extracts of $P$. arborescens were analyzed for their biological activity, which involved cytotoxicity and antioxidant assays.

\section{EXPERIMENTAL}

\section{Plant material}

The sample of $P$. arborescens was collected from Betong, Sarawak. The stem bark of $P$. arborescens was air-dried, cut into pieces and ground prior to analysis. 


\section{Extraction and isolation}

The stem bark of $P$. arborescens was extracted by conventional solvent extraction method described by Fasihuddin et al. (2010). This was achieved by soaking the ground plant material in various solvents namely hexane $\left(\mathrm{C}_{6} \mathrm{H}_{14}\right)$, dichloromethane $\left(\mathrm{CH}_{2} \mathrm{Cl}_{2}\right)$, chloroform $\left(\mathrm{CHCl}_{3}\right)$ and methanol $(\mathrm{MeOH})$, in the order of increasing polarity. The sample was first soaked in hexane for 72 hours. The resulting solution was filtered using filter paper and the residue was re-extracted with fresh hexane for another 72 hours and filtered. Both extracts were combined and concentrated with a rotary evaporator under reduced pressure to obtain the hexane crude extract. The residues were reextracted using similar procedure with dichloromethane, followed by chloroform and methanol to obtain the respective crude extracts.

Secondary metabolite from the crude extracts of $P$. arborescens was isolated and purified by using chromatographic method namely column chromatography (CC), with thin layer chromatography (TLC) as a medium for visual identification. The crude extract was fractionated by CC over silica gel 60 (Merck 70-230 Mesh @ 0.063$0.200 \mathrm{~mm}$ ) eluted with various solvent system to obtain a semi-pure and pure metabolite.

\section{Identification}

Identification of the isolated metabolite was made by various spectrometric methods namely Gas Chromatography - Mass Spectrometry (GC-MS), Nuclear Magnetic Resonance (NMR) and Fourier Transform Infrared spectrometry (FTIR) as described by previous study [3]. Analysis by GC-MS was performed on a Shimadzu model QP 2010 Plus to obtain molecular mass of the compounds according to mass-to-charge $(\mathrm{M} / \mathrm{z})$ ratio, based on the method described by Kalaiselvan et al. (2012). Nuclear Magnetic Resonance (NMR) was performed by using JEOL JNM-ECA 500 spectrometer, based on the method as described by Efdi et al. (2010). The sample was dissolved in chloroform D1 $\left(\mathrm{CDCl}_{3}\right)$, and ${ }^{1} \mathrm{H}$ and ${ }^{13} \mathrm{C}$ spectra were measured at 500 and $125 \mathrm{MHz}$, respectively. FTIR analysis was performed by using spectrometer model Nicolet iS10 SMART iTR of Thermo Scientific brand. The range of the scan for the FTIR was started from 400 to 4000 $\mathrm{cm}^{-1}$ with a resolution of $4 \mathrm{~cm}^{-1}$, according to the method described by Shalini \& Sampathkumar (2012).

\section{Cytotoxicity assay}

Cytotoxicity test against brine shrimp (Artemia salina) developed by McLaughlin (1991) was used in this study. Leached brine shrimp eggs were hatched in seawater and incubated for 48 hours at $25{ }^{\circ} \mathrm{C}$. Exactly $3 \mathrm{mg}$ of sample was dissolved in $3 \mathrm{~mL}$ methanol, and the mixture was sonicated to ensure the homogeneity of the extract. Four different volumes of $500,250,50$ and $5 \mu \mathrm{L}$ each of the stock solution were transferred into Nunc multidish in triplicate. The solvent was allowed to evaporate under a running fume hood for overnight, and followed by the addition of $0.2 \mathrm{~mL}$ dimethylsulphoxide (DMSO) and $4.8 \mathrm{~mL}$ seawater to give a final concentration of $100,50,10$ and 1 $\mu \mathrm{g} / \mathrm{mL}$, respectively. Ten brine shrimp nauplii were transferred into each concentration in the multidish, and was observed every 6 hours for 24 hours. The numbers of dead nauplii were observed. Thymol was used as positive control, whereas $0.2 \mathrm{~mL}$ dimethylsulphoxide (DMSO) and $4.8 \mathrm{~mL}$ seawater was used as negative control. The data was analyzed to determine the concentration of the samples that kill $50 \%$ of brine shrimp at 24 hours or known as $\mathrm{LC}_{50}$. LC 50 was calculated and determined by performing Probit analysis in IBM SPSS Statistic software of version 21 .

\section{Antioxidant assay}

The free radical scavenging assay of compound 2,2-diphenyl-1pycryl-hydrazyl (DPPH) was used to evaluate the antioxidant properties of the crude extracts. The measurement was based on the method as described by Wang et al. (2008). Four concentration of sample were prepared at $10,50,100$ and $1000 \mu \mathrm{g} / \mathrm{mL}$ from each crude extract, by diluting the crude extract with a methanol.

Approximately $3 \mathrm{~mL}$ of $0.1 \mathrm{mM}$ methanol solution of 2,2 diphenyl-1-pycrylhydrazyl (DPPH) was each added into the $1 \mathrm{~mL}$ each of four series of prepared sample concentrations, making a final concentration of $2,12,25$ and $250 \mu \mathrm{g} / \mathrm{mL}$, respectively. The analysis was done in triplicate. The solution was mixed vigorously and left to stand at room temperature for $30 \mathrm{~min}$ in the darkness after which its absorbance was measured spectrophotometrically at $517 \mathrm{~nm}$, performed by ultraviolet spectrophotometer. Methanol was used as a blank sample and negative control ( $1 \mathrm{~mL}$ methanol: $3 \mathrm{~mL} \mathrm{DPPH})$, while ascorbic acid (vitamin C) as the standard. The value of $\mathrm{EC}_{50}$ was determined using log dose inhibition curve (Tailor \& Goyal, 2014) which performed by using PRISM version 3.02 software, based on the calculated values of the DPPH scavenging activity (\%) of the sample.

\section{RESULTS AND DISCUSSION}

Six secondary metabolites have been isolated from the stem bark of $P$. arborescens, which reveal the presence of two terpenes namely caryophyllene oxide $\left(\mathrm{C}_{15} \mathrm{H}_{24} \mathrm{O}\right)$ (1) and $\alpha$-bisabolol $\left(\mathrm{C}_{15} \mathrm{H}_{26} \mathrm{O}\right)(2)$, along with three alkaloids namely benzamide 2-(methylamino) $\left(\mathrm{C}_{8} \mathrm{H}_{10} \mathrm{~N}_{2} \mathrm{O}\right)$ (3), 2-ethylpiperidine $\left(\mathrm{C}_{7} \mathrm{H}_{15} \mathrm{~N}\right)$ (4) and piperine $\left(\mathrm{C}_{17} \mathrm{H}_{19} \mathrm{NO}_{3}\right)$ (5), and one phenylpropanoid identified as methyl eugenol $\left(\mathrm{C}_{11} \mathrm{H}_{14} \mathrm{O}_{2}\right)(\mathbf{6})$.

\section{Caryophellene oxide}

Compound caryophyllene oxide (1) was isolated as white yellowish crystalline, isolated from the methanol crude extract of $P$. arborescens. The crude extract was fractionated by column chromatography eluted with hexane : ethyl acetate (4:1), (9:1). Analysis of compound (1) in TLC plate shows the $\mathrm{R}_{\mathrm{f}}$ value of 0.66 in hexane : ethyl acetate (9:1) as mobile phase, viewed after staining with vanillin dipping reagent. Melting point $60-63{ }^{\circ} \mathrm{C}$. GC-MS $\left[\mathrm{C}_{15} \mathrm{H}_{24} \mathrm{O}\right]$ (S.I. 93\%); IR Vmax cm ${ }^{-1}$ : 2926, 1630, 1453, 861; MS m/z (\% rel. int): 220 (8), 205 (10), 187 (10), 177 (10), 161 (10), 149 (12), 135 (15), 121 (35), 109 (55), 93 (95), 79 (100), 69 (75), 43 (95), 41 (75); ${ }^{1} \mathrm{H}-\mathrm{NMR}\left(500 \mathrm{MHz}, \mathrm{CDCl}_{3}\right) \delta(\mathrm{ppm})$ : 4.96 (s, 1H, H-15a), 4.85 (s, 1H, H-15b), 2.87 (t, J = 5.4 Hz, 1H, H-1), $2.61(\mathrm{q}, \mathrm{J}=9.4 \mathrm{~Hz}, 1 \mathrm{H}, \mathrm{H}-8), 2.37-2.21(\mathrm{~m}, 2 \mathrm{H}, \mathrm{H}-10), 2.13-2.06(\mathrm{q}$, 1H, H-5), 1.75 (t, J = 9.9 Hz, 2H, H-3), 1.68-1.57 (q, 4H, H-2, H-9), 1.36 (d, J = 59.6 Hz, 2H, H-6), 1.19 (s, 3H, H-12), 1.00 (s, 3H, H-13), 0.97 (s, 3H, H-14); ${ }^{13} \mathrm{C}-\mathrm{NMR}\left(125 \mathrm{MHz}, \mathrm{CDCl}_{3}\right) \delta(\mathrm{ppm}): 151.91(\mathrm{C}-$ 4), 112.88 (C-15), 63.89 (C-1), 59.99 (C-11), 50.72 (C-8), 48.83 (C-5), 39.20 (C-6), 39.81 (C-10), 34.13 (C-7), 30.31 (C-2), 29.98 (C-3), 29.80 (C-9), 27.28 (C-14), 21.70 (C-13), 17.10 (C-12).

Both ${ }^{1} \mathrm{H}-\mathrm{NMR}$ and ${ }^{13} \mathrm{C}-\mathrm{NMR}$ signals of compound (1) were associated with the one produced in the NMR signal of caryophyllene oxide reported by Morten \& Sparling (2007), while the IR spectrum indicated similarity with caryophyllene oxide reported by Gohari et al. (2005). Caryophyllene oxide (1) is a natural product grouped in terpene, derivatives of caryophyllene, which usually used as food and flavour ingredients, apart from its wide application in the perfumery industry for aromatic purposes. Caryophyllene oxide (1) has been approved by the Food and Drug Administration (FDA) and European Food Safety Autority (EFSA) as a natural flavoring. According to the information published by www.terpenes.info.com, caryophyllene oxide (1) can give benefit as anti-fungal and as an anticoagulant. A study by Chavan et al. (2010) reported that caryophyllene oxide (1) was comparable to standard aspirin, which showed a significant inhibition of inflammatory adema. Besides, caryophyllene oxide (1) was reported to possess significant anticancer activities as reported by Fidyt et al. (2016). Beside been identified in the crude extract of $P$. arborescens in this study, the occurrence of caryophyllene oxide (1) also reported in the essential oil of various Piper spp. namely the $P$. nigrum, $P$. porphyrophyllum, $P$. aduncum, $P$. arborescens, $P$. erecticaule and P.betle as reported by Irna et al. (2012) and Chieng et al. (2003).

\section{$\boldsymbol{\alpha}$-bisabolol}

Compound $\alpha$-bisabolol (2) was obtained also from the methanol crude extract of $P$. arborescens. It was obtained as an amorphous form with yellowish colour. The crude extract was fractionated by column chromatography eluted with hexane : ethyl acetate (4:1), (9:1). TLC test on compound (2) shows $R_{f}$ value of 0.34 in hexane : ethyl acetate $(9: 1)$, viewed after staining with vanillin dipping reagent. GC-MS $\left[\mathrm{C}_{15} \mathrm{H}_{26} \mathrm{O}\right]$ (S.I. 96\%); IR Vmax cm ${ }^{-1}$ : 3445, 2921, 1719, 1375, 913; MS m/z (\% rel. int): 204 (20), 189 (10), 161 (15), 148 (10), 134 (15), 119 (100), 
109 (95), 93 (48), 71 (28), 69 (90), 43 (80), 41 (40); ${ }^{1} \mathrm{H}-\mathrm{NMR}(500$ $\left.\mathrm{MHz}, \mathrm{CDCl}_{3}\right) \delta(\mathrm{ppm}): 5.39(\mathrm{t}, \mathrm{J}=2.0 \mathrm{~Hz}, 1 \mathrm{H}, \mathrm{H}-10), 5.12(\mathrm{t}, \mathrm{J}=6.3$ $\mathrm{Hz}, 1 \mathrm{H}, \mathrm{H}-6), 2.39-2.14$ (t, 2H, H-2), 2.07-1.96 (t, 2H, H-5), 1.83 (dd, $\mathrm{J}=41.0,12.9 \mathrm{~Hz}, 2 \mathrm{H}, \mathrm{H}-9), 1.68(\mathrm{~s}, 1 \mathrm{H}, \mathrm{O}-\mathrm{H}), 1.61$ (s, 3H, H-15), 1.561.45 (m, 1H, H-4), 1.33-1.23 (m, 8H, H-3, H-12, H-13), 1.13 (s, 3H, H14), $0.87(\mathrm{t}, \mathrm{J}=6.9 \mathrm{~Hz}, 2 \mathrm{H}, \mathrm{H}-8) ;{ }^{13} \mathrm{C}-\mathrm{NMR}\left(125 \mathrm{MHz}, \mathrm{CDCl}_{3}\right) \delta$ (ppm): 133.98 (C-1), 131.90 (C-11), 124.65 (C-10), 120.86 (C-6), 74.48 (C-7), 43.39 (C-4), 39.39 (C-8), 31.07 (C-2), 29.80 (C-5), 26.17 (C-3), 25.88 (C-9), 24.07 (C-12), 23.47 (C-13), 22.38 (C-14), 17.79 (C$15)$.

${ }^{1} \mathrm{H}-\mathrm{NMR}$ and ${ }^{13} \mathrm{C}-\mathrm{NMR}$ signal of compound (2) was identical with the NMR signals of $\alpha$-bisabolol from the previous study by Luiz Gustavo et al. (2015). Besides, IR spectrum of compound (2) shows similarity to IR stretching and bending vibrations of $\alpha$-bisabolol reported by Santos Nara et al. (2013). $\alpha$-bisabolol (2) is a natural monocyclic sesquiterpene, a metabolite in a group of terpenes. Previous study done by Chieng et al. (2003) had detected $\alpha$-bisabolol (2) in the essential oils of four Piper spp. namely the $P$. arborescens, $P$. sarmentosum, $P$. erecticaule, and $P$. betle, with $P$. erecticaule contained the highest percentage of $0.67 \%$, while $0.21 \%$ was found in $P$. arborescens. In natural product application, $\alpha$-bisabolol (2) usually associated as an analgesic, anti-bacterial, anti-inflammatory, antimutagenic, antioxidant, anticancer and as a neuroprotectant, as mentioned in www.terpene.info and reported by Santos Nara et al. (2013). Hence, $\alpha$-bisabolol has been widely used in dermatological and cosmetic industries as body lotions, after-shave cream, deodorants, lips sticks, and in sun-care, baby-care and sports products. The combination of a natural product of $\alpha$-bisabolol with the conventional drug demonstrated an enhance in antibacterial activity against resistant bacteria pathogens (Santos Nara et al., 2013)

\section{Benzamide 2-(methylamino)}

Compound benzamide 2-(methylamino) (3) was isolated as crystalline form with pale brown colour from methanol crude extract of $P$. arborescens. The crude extract was fractionated by column chromatography eluted with hexane : ethyl acetate (4:1), (2:1), (1:1), followed by re-column with dichloromethane $100 \%$, dichloromethane : ethyl acetate (5:1). Analysis of compound (3) in TLC plate shows $R_{f}$ value of 0.42 (uv) in hexane : ethyl acetate (3:1) as mobile phase. Melting point $160-162{ }^{\circ} \mathrm{C}$. GC-MS $\left[\mathrm{C}_{8} \mathrm{H}_{10} \mathrm{~N}_{2} \mathrm{O}\right.$ ] (S.I. 78\%); IR Vmax $\mathrm{cm}^{-1}$ : 3324, 2975, 1604, 1516, 1107, 909; MS m/z (\% rel. int): 150 (100), 123 (48), 103 (50), 91 (10), 77 (50), 65 (10), 51 (32), $40(8) ;{ }^{1} \mathrm{H}-$ NMR $\left(500 \mathrm{MHz}, \mathrm{CDCl}_{3}\right) \delta(\mathrm{ppm}): 6.77(\mathrm{~d}, \mathrm{~J}=8.0 \mathrm{~Hz}, 1 \mathrm{H}, \mathrm{H}-5), 6.69$ (d, J = 1.7 Hz, 1H, H-3), 6.60 (d, J = 8.0 Hz, 1H, H-2), 5.91 (s, 2H, N$\left.\mathrm{H}_{2}\right), 5.04(\mathrm{t}, \mathrm{J}=10.3 \mathrm{~Hz}, 1 \mathrm{H}, \mathrm{H}-4), 3.25(\mathrm{~s}, 3 \mathrm{H}, \mathrm{H}-8), 2.50(\mathrm{~s}, 1 \mathrm{H}, \mathrm{N}-$ $\mathrm{H}) ;{ }^{13} \mathrm{C}-\mathrm{NMR}\left(125 \mathrm{MHz}, \mathrm{CDCl}_{3}\right) \delta(\mathrm{ppm}): 143.58(\mathrm{C}-7), 141.78(\mathrm{C}-4)$, 137.77 (C-3), 133.34 (C-2), 121.12 (C-5), 115.92 (C-1), 115.60 (C-6), $39.59(\mathrm{C}-8)$.

Compound benzamide 2-(methylamino) (3) is less explored and related research publication is very limited. Benzamide 2(methylamino) (3) is categorized in alkaloid group, a compound derived from benzamide. Benzamide derivatives have been extracted from various natural sources (Anonymous, 2016a) with several of it have been synthesized from natural anacardic acid, a major constituent of cashew nut shell as reported in Vittal Mallya's Scientific Research Foundation of Natural Product Derivatives. According to Anonymous (2016a), several benzamide derivatives have been biologically evaluated which the result indicated the compounds were with great potential as an agent for antimicrobial, antifungal, anti-enterovirus, antihypertensive and antioxidant.

\section{2-ethylpiperidine}

Compound 2-ethylpiperidine (4) was isolated from the chloroform crude extract of $P$. arborescens. The compound was isolated as pale white brown powder. The crude extract was fractionated in a three series of column chromatography started with hexane $100 \%$, hexane : dichloromethane (1:1), dichloromethane $100 \%$, dichloromethane : chloroform (1:1), chloroform $100 \%$, chloroform : ethyl acetate (1:1), ethyl acetate $100 \%$, ethyl acetate : methanol (1:1). Re-column of the fractions was performed with chloroform : ethyl acetate (9:1), (1:1), $(1: 10),(1: 15)$, ethyl acetate $100 \%$, ethyl acetate : methanol (1:1), followed by the third re-column by using ethyl acetate : methanol (10:1), (1:1). TLC test on compound (4) shows the $\mathrm{R}_{\mathrm{f}}$ value of 0.48 (uv) in the ethyl acetate : methanol (12:1) as mobile phase. Melting point 172-176 ${ }^{\circ}$ C. GC-MS; $\left[\mathrm{C}_{7} \mathrm{H}_{15} \mathrm{~N}\right]$ (S.I. 86\%); IR Vmax cm ${ }^{-1}: 3372,2924$, 1249, 1017; MS m/z (\% rel. int): 112 (10), 84 (100), 69 (10), 40 (10); ${ }^{1} \mathrm{H}-\mathrm{NMR}\left(500 \mathrm{MHz}, \mathrm{CDCl}_{3}\right) \delta(\mathrm{ppm}): 3.89(\mathrm{~s}, 1 \mathrm{H}, \mathrm{N}-\mathrm{H}), 3.64-3.41(\mathrm{~m}$, $3 \mathrm{H}, \mathrm{H}-5, \mathrm{H}-4), 1.79-1.63$ (q, 2H, H-1), 1.63-1.50 (m, 2H, H-6), 1.381.20 (m, 4H, H-2, H-3), 0.87 (t, J = 6.9 Hz, 3H, H-7); ${ }^{13} \mathrm{C}-\mathrm{NMR}(125$ $\left.\mathrm{MHz}, \mathrm{CDCl}_{3}\right) \delta(\mathrm{ppm}): 47.62$ (C-4), 43.22 (C-5), 29.85 (C-1), 26.41 (C2), 25.64 (C-3), 24.53 (C-6), 14.21 (C-7).

IR spectrum of compound (4) shows similarity with the published IR data on 2-ethylpiperidine reported by Anonymous (2002). Comparison with proton NMR signals reported by Abraham (2008) showed that compound (4) was similar to 2-ethylpiperidine. Besides, the predicted ${ }^{1} \mathrm{H}-\mathrm{NMR}$ and ${ }^{13} \mathrm{C}$-NMR spectrum of 2-ethylpiperidine provided by www.nmrdb.org showed a high similarity with NMR spectrum of compound (4) in term of chemical shift and pattern for every signal. Compound 2-ethylpiperidine (4) is categorized in the alkaloid group, a derivative from piperidine. It is an organic compound that usually found in black pepper, also being reported found in various Piper spp. (Reshmi et al., 2010) and the presence of 2-ethylpiperidine (4) in P. arborescens was further discovered in this study. Piperidine and 2-ethylpiperidine (4) were extracted and mainly used in pharmaceutical and agro-industry (Scherer, 2003).

\section{Piperine}

Compound piperine (5) was isolated as white powder from the dichloromethane crude extract of $P$. arborescens. The crude extract was initially dissolved with some dichloromethane and cooled in an icebath. Diethyl ether was added into the solution. The solution was stirred gently until precipitation occured. The solidified residue was filtered, and then dissolved in ethanol and $10 \%$ potassium hydroxide. The solution was concentrated using rotary evaporator to obtain the crude extract. The crude extract was then fractioned by column chromatography, eluted with dichloromethane : ethyl acetate $(6: 4)$, (4:6). Analysis of compound (5) in TLC plate shows $R_{f}$ value of 0.46 (uv) in dichloromethane as mobile phase. Melting point $126-128{ }^{\circ} \mathrm{C}$. GC-MS $\left[\mathrm{C}_{17} \mathrm{H}_{19} \mathrm{NO}_{3}\right]$ (S.I. 96\%); IR Vmax cm $\mathrm{cm}^{-1}$ : 2934, 1624, 1578, 1437, 1245, 1023; MS m/z (\% rel. int): 285 (70), 201 (95), 173 (48), 159 (10), 143 (30), 137 (15), 115 (100), 100 (10), 84 (40), 63 (10), 55 (10), 40 (10); ${ }^{1} \mathrm{H}-\mathrm{NMR}\left(500 \mathrm{MHz}, \mathrm{CDCl}_{3}\right) \delta(\mathrm{ppm}): 7.39(\mathrm{q}, \mathrm{J}=7.9 \mathrm{~Hz}$, $1 \mathrm{H}, \mathrm{H}-5), 6.97$ (d, J = 1.5 Hz, 1H, H-10), $6.88(\mathrm{dd}, \mathrm{J}=8.0,1.9 \mathrm{~Hz}, 1 \mathrm{H}$, H-6), 6.77 (s, 1H, H-8), 6.76 (s, 1H, H-9), 6.73 (d, J = 9.2 Hz, 1H, H4), 6.43 (d, J = 14.5 Hz, 1H, H-11), 5.96 (s, 2H, H-1), 3.57 (d, J = 55.8 $\mathrm{Hz}, 4 \mathrm{H}, \mathrm{H}-13, \mathrm{H}-17), 1.65$ (m, J = 5.9 Hz, 2H, H-15), 1.58 (m, J = 5.7 $\mathrm{Hz}, 4 \mathrm{H}, \mathrm{H}-14, \mathrm{H}-16) ;{ }^{13} \mathrm{C}-\mathrm{NMR}\left(125 \mathrm{MHz}, \mathrm{CDCl}_{3}\right) \delta$ (ppm): 165.51 (C-12), 148.27 (C-2), 148.19 (C-3), 142.57 (C-10), 138.30 (C-8), 131.10 (C-7), 125.43 (C-9), 122.60 (C-5), 120.14 (C-11), 108.58 (C-4), 105.75 (C-6), 101.36 (C-1), 47.00 (C-13), 43.33 (C-17), 26.82 (C-14), 25.71 (C-16), 24.76 (C-15).

Comparison of IR spectrum of compound (5) showed that it was identical to IR data of piperine reported by Saha et al. (2013), while comparison of ${ }^{1} \mathrm{H}-\mathrm{NMR}$ and ${ }^{13} \mathrm{C}-\mathrm{NMR}$ signals of compound (5) with NMR data of piperine reported by Gottumukkala et al. (2012) indicated similarity. Piperine (5) is a type of amide alkaloid that commonly found in various Piper spp. This compound has always been referred as a contributor for the pungency's smell and taste of the black pepper $(P$. nigrum). Malaysian Agricultural Research and Development Institute (MARDI) has developed food product known as a botanical cube and drink from $P$. arborescens. Panelist's feedback from the sensory test has mentioned a smell and taste of the product that resembles black pepper (Chua et al., 2016). This 'taste of black pepper' in P. arborescens most probably contributed by the major presence of piperine (5) as discovered and isolated in this study.

\section{Methyl eugenol}

Compound methyl eugenol (6) was isolated as yellowish amorphous from dichloromethane crude extract of $P$. arborescens. The crude extract was fractioned by column chromatography, eluted with dichloromethane $100 \%$, followed by re-column using hexane : dichloromethane $(1: 1)$ and dichloromethane $100 \%$. TLC test on 
compound (6) showed $\mathrm{R}_{\mathrm{f}}$ value of 0.54 in hexane : dichloromethane (1:1) as mobile phase. GCMS $\left[\mathrm{C}_{11} \mathrm{H}_{14} \mathrm{O}_{2}\right]$ (S.I. $86 \%$ ); IR Vmax $\mathrm{cm}^{-1}$ : 2924, 1739, 1258, 1030; MS m/z (\% rel. int): 178 (68), 163 (25), 147 (30), 135 (20), 115 (30), 103 (70), 91 (100), 77 (50), 65 (48), 51 (45), 45 (10); ${ }^{1} \mathrm{H}-\mathrm{NMR}\left(500 \mathrm{MHz}, \mathrm{CDCl}_{3}\right) \delta(\mathrm{ppm}): 6.80(\mathrm{~d}, \mathrm{~J}=7.6 \mathrm{~Hz}, 2 \mathrm{H}$, H-6, H-9), 6.72 (d, J = 10.7 Hz, 1H, H-5), 6.00-5.91 (m, 1H, H-2), 5.08 (d, J = 15.3 Hz, 2H, H-1), 3.87 (s, 6H, H-10, H-11), 3.33 (d, J = 6.1 Hz, 2H, H-3); ${ }^{13} \mathrm{C}-\mathrm{NMR}\left(125 \mathrm{MHz}, \mathrm{CDCl}_{3}\right) \delta$ (ppm): 148.94 (C-7), 147.43 (C-8), 137.78 (C-2), 132.70 (C-4), 120.46 (C-5), 115.70 (C-1), 111.89 (C-6), 111.28 (C-9), 56.00 (C-11), 55.86 (C-10), 39.89 (C-3).

These is similar between IR spectrum of compound (6) and IR spectrum of methyl eugenol reported by Riyanto et al. (2016). Proton NMR of compound (6) was comparable with ${ }^{1} \mathrm{H}-\mathrm{NMR}$ data of methyl eugenol reported by Raquel et al. (2011), whereas carbon NMR was similar to ${ }^{13} \mathrm{C}-\mathrm{NMR}$ data of the same compound reported by Anonymous (2016b). Methyl eugenol (6) is a phenylpropanoid chemical, which is derived from eugenol, a product from phenylalanine or known as essential amino acid. Methyl eugenol (6) can be found in many plant species especially in spices and medicinal plants. The presence of methyl eugenol (6) in P. arborescens is further supported in this study by the isolation of the compound from the dichloromethane crude extract. A study by Raquel et al. (2011) reported that methyl eugenol (6) showed antifungal activity against Candida spp. and Microsporum canis, and suggesting for more studies in the future as its parent compound known as eugenol is skin irritants.

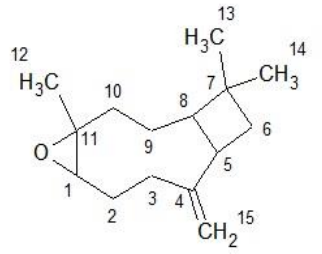

(1)<smiles>CNc1ccccc1C(N)=O</smiles>

(3)

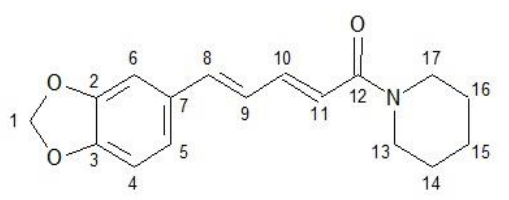

(5)<smiles>CCC1CCCCN1</smiles>

(4)

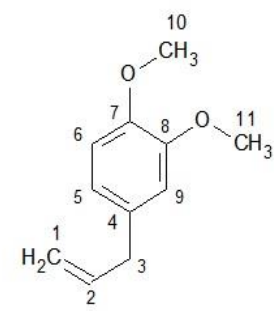

(6)

Fig. 1 Chemical structure of six secondary metabolites isolated from $P$. arborescens.

\section{Cytotoxicity activity}

Hexane and dichloromethane crude extracts of $P$. arborescens showed strong cytotoxic activity against the brine shrimp with $\mathrm{LC}_{50}$ values of 13.12 and $16.51 \mu \mathrm{g} / \mathrm{mL}$, respectively. Average death of the brine shrimp in chloroform crude extract was slightly lower with $\mathrm{LC}_{50}$ value at $26.56 \mu \mathrm{g} / \mathrm{mL}$. Methanol crude extract showed the lowest cytotoxic activity against the brine shrimp with $\mathrm{LC}_{50}$ of $58.70 \mu \mathrm{g} / \mathrm{mL}$. At higher concentration of $100 \mu \mathrm{g} / \mathrm{mL}$, methanol crude extract caused a number of $8 \pm 0.57$ death of the brine shrimp (Table 1) or an average of $75 \%$, whereas in hexane, dichloromethane and chloroform crude extracts the average death were up to $95-100 \%$ at the similar concentration, as illustrated in Fig. 2.

Based on the information reported by Moshi et al. (2010), the test sample that showed $\mathrm{LC}_{50}$ between $30-100 \mu \mathrm{g} / \mathrm{mL}$ is categorized as mildly toxic, whereas those with $\mathrm{LC}_{50}$ more than $100 \mu \mathrm{g} / \mathrm{mL}$ are considered as being practically low or non-toxic. With this guideline, the result from this study showed that the four crude extracts from $P$. arborescens were categorized as toxic for having $\mathrm{LC}_{50}$ values ranging from 13.12 to $58.70 \mu \mathrm{g} / \mathrm{mL}$. Hexane $\left(\mathrm{LC}_{50} 13.12 \mu \mathrm{g} / \mathrm{mL}\right)$, dichloromethane ( $\mathrm{LC}_{50} 16.51 \mu \mathrm{g} / \mathrm{mL}$ ) and chlorofom (LC50 26.56 $\mu \mathrm{g} / \mathrm{mL}$ ) crude extracts of $P$. arborescens can be considered as highly toxic because the $\mathrm{LC}_{50}$ are lower than $30-100 \mu \mathrm{g} / \mathrm{mL}$ (mildly toxic) as suggested by Moshi et al. (2010).

Greater cytotoxic activity of the four crude extacts of $P$. arborescens towards brine shrimp indicated the presence of potent cytotoxic components in this Piper spp. Studies by Moshi et al. (2010) suggested that some of the plant extracts with $\mathrm{LC}_{50}$ below $100 \mu \mathrm{g} / \mathrm{mL}$ which are categorized as toxic, does not always indicated its danger or outright toxicity toward human, but may also suggest a potential antitumor or anticancer activities.

Table 1. Average death of Artemia salina at different concentrations of crude extracts of $P$. arborescens.

\begin{tabular}{|c|c|c|c|c|c|}
\hline \multirow{3}{*}{ Crude extracts } & \multirow{2}{*}{\multicolumn{4}{|c|}{$\begin{array}{l}\text { Average death of Artemia } \\
\text { salina } \\
\text { Concentration }(\mu \mathrm{g} / \mathrm{mL})\end{array}$}} & \multirow{3}{*}{$\begin{array}{c}\mathrm{LC}_{50} \\
(\mu \mathrm{g} / \mathrm{mL})\end{array}$} \\
\hline & & & & & \\
\hline & 1 & 10 & 50 & 100 & \\
\hline Hexane extract & 0 & $\begin{array}{c}2 \pm \\
1.15\end{array}$ & $\begin{array}{l}10 \pm \\
0.00\end{array}$ & $\begin{array}{l}10 \pm \\
0.00\end{array}$ & 13.12 \\
\hline $\begin{array}{l}\text { Dichloromethane } \\
\text { extract }\end{array}$ & 0 & $\begin{array}{c}2 \pm \\
1.00\end{array}$ & $\begin{array}{l}10 \pm \\
0.57\end{array}$ & $\begin{array}{l}10 \pm \\
0.00\end{array}$ & 16.51 \\
\hline Chloroform extract & 0 & $\begin{array}{c}1 \pm \\
0.57\end{array}$ & $7 \pm 0.57$ & $\begin{array}{l}10 \pm \\
0.57\end{array}$ & 26.56 \\
\hline Methanol extract & 0 & 0 & $4 \pm 1.15$ & $8 \pm 0.57$ & 58.70 \\
\hline (-ve Control) & 0 & 0 & 0 & 0 & - \\
\hline (+ve Control) Thymol & $\begin{array}{c}5 \pm \\
0.57\end{array}$ & $\begin{array}{c}7 \pm \\
0.57\end{array}$ & $\begin{array}{l}10 \pm \\
0.00\end{array}$ & $\begin{array}{l}10 \pm \\
0.00\end{array}$ & 1.15 \\
\hline
\end{tabular}

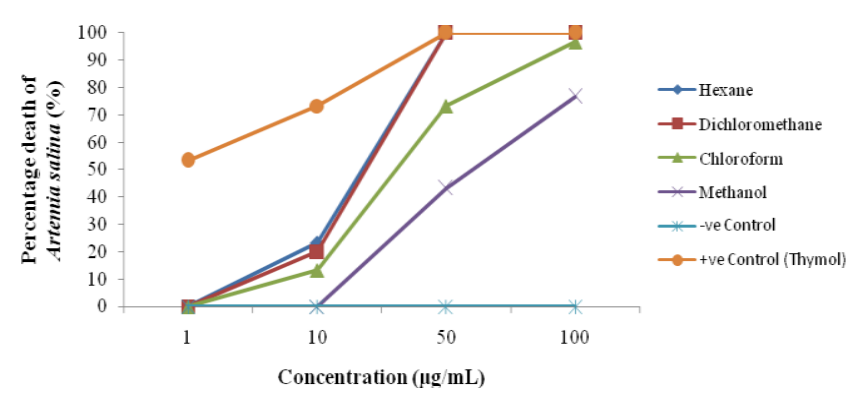

Fig. 2 Average death of Artemia salina (\%) as a function of concentration of various crude extracts of $P$. arborescens.

\section{Antioxidant activity}

Studies on antioxidant activities of the crude extracts of $P$. arborescens showed that the $\mathrm{EC}_{50}$ values of methanol, dichloromethane, chloroform and hexane crude extracts were 21.68, $23.82,32.88$ and $36.54 \mu \mathrm{g} / \mathrm{mL}$, respectively (Table 2 ), and their radical scavenging activities is shown in Fig. 3 . This shows that the crude extracts of $P$. arborescens inhibited good DPPH radical scavenging activity, which indicated good antioxidant properties. As a comparison, $\mathrm{EC}_{50}$ for ascorbic acid (standard) was $2.40 \mu \mathrm{g} / \mathrm{mL}$. Among the four crude extracts, methanol crude extract gave the best activity towards the DPPH free-radical scavenging with $\mathrm{EC}_{50}$ value at $21.68 \mu \mathrm{g} / \mathrm{mL}$. Polar extract (methanol) was reported high in phenolic content as compared with less-polar extract. The presence of polar phenolic is important in the evaluation of free radical-scavenging activity. In comparison, antioxidant activity based on $\mathrm{EC}_{50}$ value of the crude extracts from $P$. arborescens in this study were slightly greater as compared to antioxidant activities of $P$. colubrinum and $P$. nigrum, as reported by Sruthi \& John Zachariah (2017). Findings from this study suggested that the four crude extracts of $P$. arborescens potential to be used as antioxidant agents. 
Table 2. Free radical scavenging activity against DPPH radical of the crude extracts of $P$. arborescens.

\begin{tabular}{lllc}
\hline $\begin{array}{l}\text { Crude extract } \\
\text { of }\end{array}$ & Calibration equation & & $\begin{array}{l}\mathrm{EC}_{50} \\
(\boldsymbol{\mu g} / \mathbf{m L})\end{array}$ \\
\hline $\boldsymbol{P}$. arborescens & & & 36.54 \\
Hexane & $y=4.084 x+0.5457$ & $R^{2}=0.9991$ & 23.82 \\
Dichloromethane & $y=1.807 x+14.000$ & $R^{2}=0.9993$ & 32.88 \\
Chloroform & $y=1.895 x-0.5374$ & $R^{2}=0.9999$ & 32.68 \\
Methanol & $y=1.675 x-0.1976$ & $R^{2}=0.9997$ & 21.68 \\
Ascorbic acid & $y=2.346 x-279.80$ & $R^{2}=0.9957$ & 1.47 \\
\hline
\end{tabular}
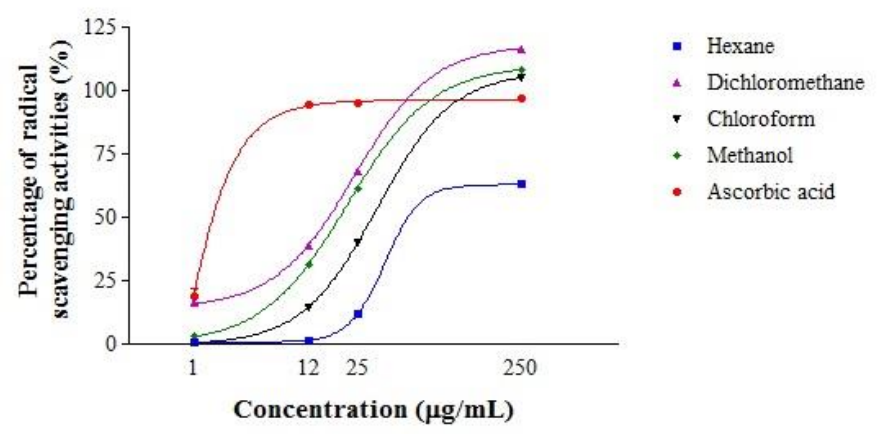

Fig. 3 Radical scavenging activity of various crude extracts of $P$. arborescens.

\section{CONCLUSION}

Extraction and purification of the stem bark of $P$. arborescens have isolated six secondary metabolites identified as caryophyllene oxide (1), $\alpha$-bisabolol (2), benzamide 2-(methylamino) (3), 2-ethylpiperidine (4), piperine (5) and methyl eugenol (6). Toxicity test was performed against Artemia salina brine shrimp and the result showed that hexane, dichloromethane, chloroform and methanol crude extracts from $P$. arborescens showed a high cytotoxic activity. Greater cytotoxic activity of the four crude extrats of $P$. arborescens indicated the presence of potent cytotoxic components in this Piper spp. as suggested by the literature. Antioxidant assay on the crude extracts of $P$. arborescens indicated moderate antioxidant properties of the crude extracts of methanol, dichloromethane, and chloroform with $\mathrm{EC}_{50}$ values ranging from 21.68 to $36.88 \mu \mathrm{g} / \mathrm{mL}$. It is suggested that the six secondary metabolites $[(\mathbf{1})$ to (6)] identified in $P$. arborescens contribute as an active content for the cytotoxicity and antioxidant activities. This study showed that the crude extracts from $P$. arborescens is definitely having potential to be used as a source of natural product.

\section{ACKNOWLEDGEMENT}

The Grant GL(F07)/MARDI/2014(12) and FRGS/1/2014/SG03 /MOA/02/1 from Universiti Malaysia Sarawak and Ministry of Education of Malaysia are gratefully acknowledged. The support received through the collaborative work of Universiti Malaysia Sarawak and Malaysian Agricultural Research and Development Institute (MARDI) in this research project is acknowledged and perhaps there will be more collaboration in the future.

\section{REFERENCES}

Abraham, R. J. 2008. Modelling 1H-NMR spectra of organic compounds. Theory, Application and NMR Prediction. Wiley, Chichester. Retrieved 20 January 2017 from http://atb.uq.edu.au/ molecule.py?nmr_solvent=CDCL3 \&nmr_freq=500\&molid=37739\#panel-nmr.

Anonymous, 2016a. Overview on the chemistry of benzamide and its derivatives Retrieved from http://shodhganga.inflibnet.ac.in/bitstream/10603/101063/ 10/10_chapter \%201.pdf.
Anonymous, 2016b. Methyl eugenol ${ }^{13}$ CNMR. Chemical book. Retrieved from http://www.chemicalbook.com/SpectrumEN_93-15-2_13CNMR.htm.

Anonymous, 2002b. Answer Key Summer 2002. Spectrum 9: 2-Ethylpiperidine. Retrieved from http://www.chem.ucla.edu/ bacher/General/30BL/problems/ spectroscopy/assignmentSu02/key.

Chavan, M. J., Wakte, P. S. \& Shinde, D. B. 2010. Analgesic and antiinflammatory activity of caryophyllene oxide from Annona squamosa L. bark. Phytomedicine, 17(2): 149-151.

Chieng, T. C., Assim, Z. B. \& Fasihuddin B. A. 2003. The essential oils profile of selected Piper species. Analytical Chemistry: Application and current issues. Sarawak: Universiti Malaysia Sarawak. pp. 169-174.

Chua, H. P., Syahida, M., Nicholas, D. \& Suzalyna, M. 2016. Piperia - Antiinflammatory botanical cube. MARDI Science and Technology Exhibition 2016. MAEPS. 11-10 December 2016.

Efdi, M., Fujita, S., Inuzuka, T. \& Koketsu, M. 2010. Chemical studies on Goniothalamus tapis Miq. Natural Product Research, 24, 7, 657-662.

Fasihuddin, B. A., Khairun Nisa, N. M. S. \& Assim, Z. B. 2010. Chemical constituents and antiviral study of Goniothalamus velutinus. Journal of Fundamental Science, 6(1): 73-76.

Gohari, A. R., Abbas, Hadjiakhoondi, A., Esmaeil, S., Ebrahimi, S., Saeidnia, S. $\&$ Shafiee, A. 2005. Cytotoxic terpenoids from Satureja macrantha C.A. Mey. DARU, 13(4): 177-181.

Gottumukkala, V. R., Kolisetty, S. R., Triptikumar, M. \& Madhavi, M. S. L. 2012. Alkamides and their biological activity from Piper longum Linn. Journal of Pharmacy Research, 5(1): 165-168.

Irna, S. S., Assim, Z. B., Fasihuddin, B. A. \& Ismail, J. 2012. The composition and variability of the leaf oils in three Piper spp. from Sarawak. In: Taxonomy \& Ecology - Beyond Classical Approaches, Fasihuddin, B. A., Sepiah, M., Isa, B. I., Ramlah, Z., Mohd Effendi, W., Meekiong, K. \& Assim, Z. B., p. 119131. Universiti Malaysia Sarawak.

Kalaiselvan, A., Gokulakrishnan, K. \& Anand, T. 2012. Gas chromatography mass spectrum analysis of bioactive components of the ethanol extract of Andrographis paniculata. Journal of Pharmaceutical and Biomedical Science, 20: 15, 1-3.

Lee, F. P., Chen, Y. C., Chen, J. J., Tsai, I. L. \& Chen, I. S. 2004. Cyclobutanoid amides from Piper arborescens. Helvetica Chimica Acta, 87: 463-468.

Liew, K. S., Mahendran, S. \& Huzaimi, H. 2000. Time series modelling and forecasting of Sarawak black pepper price. Munich Personal RePEc Archive (MPRA), 791(13): 1-16.

Luiz Gustavo, L. G., Maria, G. C., Esther, M. F. L., Matheus, P. F., Wellington, F. \& David, L. N. 2015. Structural elucidation of a new sesquiterpene alcohol by comparative NMR studies. Records of Natural Products, 9(2): 201-207.

McLaughlin, J. L. 1991. Crown gall tumours on potato disc and brine shrimp lethality: two simple bioassay for higher plants screening and fractionation. Assay for Bioactivity. San Diego: Academic Press. pp. 2-32.

Mentor, R. H., Blagica, J., Tatjana, K. P. 2014. Toxicological evaluation of the plant products using Brine Shrimp (Artemia salina L.) model. Macedonia Pharmaceutical Bulletin, 60(1): 9-18.

Micheal, P. \& Douglas, S. 2014. Spread of the invasive species Piper aduncum via logging roads in Borneo. Journal of Tropical Conservation Science, 7(1): 35-44.

Morten, C. J. \& Sparling, B. A. 2007. Application of NMR techniques to the structural determination of caryophyllene oxide. Retrieved from https://ocw. mit.edu/courses/chemistry/5-46-organic-structure-determination spring2007/ projects/546 project1.pdf.

Moshi, M. J., Innocent, E., Magadula, J. J., Otieno, D. F., Weisheit, A. Mbabazi, P. K. \& Nondo, R. S. O. 2010. Brine shrimp toxicity of some plants used as traditional medicines in Kagera region, north western Tanzania. Tanzania Journal of Health Research, 12(1): 1-6.

Raquel, O. S. F., Selene, M. M., Erika, H. S. B., Raimunda, S. N. B., Rossana, A. C., Ynayara, C. L., Nilce, V. G. P. S., Andre, J. M., Jose, J. C. S. \& Marcos, F. G. R. 2011. Alkylphenol activity against Candida spp., and Microsporum canis: A focus on the antifungal activity of thymol, eugenol and methyl derivatives. Molecules, 16: 6422-6431.

Reshmi, S. K., Sathya, E. \& Suganya, D. P. 2010. Isolation of piperdine from Piper nigrum and its antiproliferative activity. African Journal of Pharmacy and Pharmacology, 4(8): 562-573.

Riyanto, Hardjono, S. \& Erni, F. 2016. Synthesis of methyl eugenol from crude cloves leaf oil using acid based chemical reactions. IOSR Journal of Applied Chemistry, 9(10): 105-112.

Saha, K. C., Seal, H. P. \& Noor, M. A. 2013. Isolation and characterization of piperine from the fruits of black pepper (Piper nigrum). Journal of the Bangladesh Agricultural University, 11(1): 11-16.

Scherer, M. 2003. Chemicals for Pharmaceuticals. Raschig Chemicals. Retrieved from http://www.centralchem.co.jp/image/Chem_Pharma.pdf.

Shalini, S. \& Sampathkumar, P. 2012. Phytochemical screening and antimicrobial activity of plant extracts. International Journal of Current Science, 20: 209-218.

Santos Nara, K. A., Rodrigues, F. F. G., Coutinho, H. D. M., Viana, G. S. B. \& Costa, J. G. M. 2013. Isolation of alpha-bisabolol from the essential oil of 
Vanillosmopsis arborea baker and modulation of antibiotic activity using gaseous contact. TEOP, 16(6): 826-831.

Sruthi, D. \& John Zachariah, T. 2017. In vitro antioxidant activity and cytotoxicity of sequential extracts from selected black pepper (Piper nigrum

L.) varieties and Piper species. International Food Research Journal, 24(1): $75-85$.

Tailor, C. S. \& Goyal, A. 2014. Antioxidant activity by DPPH radical scavenging method of Ageratum conyzoides Linn. leaves. American Journal of Ethnomedicine, 1(4): 244-249.
Tsai, I. L., Lee, F. P., Wu, C. C., Duh, C. Y., Ishikawa, T., Chen, J. J., Chen, Y. C., Seki, H. \& Chen, I. S. 2005. New cytotoxic cyclobutanoid amides, a new furanoid lignan and anti-platelet aggregation constituents from Piper arborescens. Planta Medica, 71: 535-542.

Wang, H., Zhao, M., Yang, B., Jiang, Y. \& Rao, G. 2008. Identification of polyphenols in tobacco leaf and their antioxidant and antimicrobial activities. Food Chemistry, 107: 1399-1406. 